\title{
Managing severe behavioral symptoms of a patient with anti-NMDAR encephalitis: case report and findings in current literature
}

\author{
Manejo de sintomas comportamentais severos em um paciente com \\ encefalite anti-NMDAR: relato de caso e literatura atual
}

Vanina Lima Monteiro, ${ }^{1}$ Felipe José Nascimento Barreto, ${ }^{1}$ Paulo Marcos Brasil Rocha, ${ }^{1}$ Paulo Henrique Teixeira do Prado, ${ }^{1}$ Frederico Duarte Garcia, ${ }^{2}$ Humberto Correa, ${ }^{2}$ Maila Castro Lourenço das Neves ${ }^{2}$

\begin{abstract}
Objective: Psychiatric symptoms emerge in the early stages of anti-N-methyl-D-aspartate receptor (anti-NMDAR) encephalitis, and patients often seek treatment in psychiatric departments before visiting any other general medical services. Numerous articles about anti-NMDAR encephalitis have been published in the scientific community worldwide, but few emphasize the role of psychiatry in symptom management.

Case description: We describe the case of a patient with anti-NMDAR encephalitis seen in our service and discuss the management of behavioral symptoms based on current scientific literature. High doses of atypical antipsychotics and benzodiazepines were used to control agitation, and trazodone was administered to treat insomnia.

Comments: Consultation-liaison psychiatry may help the healthcare team adjust the management of neuropsychiatric complications that might affect inpatients with anti-NMDAR encephalitis.

Keywords: Anti-NMDAR encephalitis, consultation-liaison psychiatry, behavioral symptoms.
\end{abstract}

\section{Introduction}

The clinical course of anti-N-methyl-D-aspartate receptor (anti-NMDAR) encephalitis has a myriad of neurological and psychiatric features, such as delusions and hallucinations, but also agitation, disorganized thinking, affective lability and catatonia. ${ }^{1,2}$ Surprisingly, $7.8 \%$ of the patients with schizophrenia or other psychotic disorders have serum antibodies for this disease. ${ }^{3}$ Because psychiatric symptoms emerge

\section{Resumo}

Objetivo: Sintomas psiquiátricos surgem em estágios precoces da encefalite antirreceptor $\mathrm{N}$-metil-D-aspartato (NMDAR), o que faz muitos pacientes procurarem tratamento em serviços de psiquiatria antes de se dirigirem a unidades de clínica geral. Embora muitos artigos sobre encefalite anti-NMDAR venham sendo publicados na comunidade científica internacional, poucos enfatizam o papel do psiquiatra no seu manejo sintomatológico. Descrição do caso: $O$ presente artigo relata o caso de um paciente que desenvolveu encefalite anti-NMDAR em nosso serviço e discute manejo de alterações comportamentais com base na literatura científica atual. Altas doses de antipsicóticos atípicos e benzodiazepínicos foram usados para controle de agitação, e trazodona foi utilizada para tratar insônia.

Comentários: A interconsulta psiquiátrica pode ajudar no ajuste de condutas de toda a equipe assistente para as complicações neuropsiquiátricas que possam surgir na evolução de pacientes internados por encefalite anti-NMDAR.

Descritores: Encefalite anti-NMDAR, interconsulta psiquiátrica, sintomas comportamentais.

in the early stages of anti-NMDAR encephalitis, $77 \%$ of the patients are not seen in a general healthcare service before seeking treatment in a psychiatric department, ${ }^{4}$ where this disease may be mistaken for primary psychiatric conditions, such as brief psychosis disorder, drug-induced psychosis or mania. ${ }^{1,5}$ Moreover, $4 \%$ of the patients present with isolated psychiatric symptoms. ${ }^{6}$ As anti-NMDAR encephalitis is not initially suspected, the treatment of this potentially lethal disorder may be delayed.

\footnotetext{
${ }^{1}$ Universidade Federal de Minas Gerais (UFMG), Belo Horizonte, MG, Brazil. ${ }^{2}$ Mental Health Department, UFMG, Belo Horizonte, MG, Brazil. Financial support: none.

Submitted Aug 17 2014, accepted for publication Oct 09 2014. No conflicts of interest declared concerning the publication of this article.

Suggested citation: Monteiro VL, Barreto FJ, Rocha PM, Prado PH, Garcia FD, Correa H, et al. Managing severe behavioral symptoms of a patient with anti-NMDAR encephalitis: case report and findings in current literature. Trends Psychiatry Psychother. 2015;37(1):47-50. http://dx.doi.org/10.1590/2237-6089-2014-0036. Epub Jan 30, 2015.
} 
To this date, numerous articles about anti-NMDAR encephalitis have been published in the scientific community worldwide, $1,2,4,7$ but few emphasize the role of psychiatrists in the management of this disease while clinical signs and symptoms persist without remission. Furthermore, there is still little information about the pharmacological options for the treatment of the behavioral symptoms of patients with this disease. ${ }^{8-10}$ We report the case of a patient with antiNMDAR encephalitis seen in our service and discuss psychiatric symptom management based on current literature. This report was approved by our local ethics committee, and the patient signed an informed consent form.

\section{Case description}

A 30-year-old Brazilian single male computer technician was taken to the hospital by his mother. Two days before, he had suddenly begun behaving strangely: his speech included meaningless words and alternated with silence, insomnia and restlessness. His history revealed no fever, seizures or recent physical trauma. Substance abuse, exogenous intoxication or previous contact with heavy metals were excluded, as well as personal and family history of psychiatric illnesses. According to his mother, the patient collected old computer parts and did not have many social interactions. Physical and neurological examinations were normal. During the examination, his behavior was restless and unsuitable: he crouched on the floor, stood up, lay down, sat up, pointed to himself and to his examiner alternately, climbed several times on the scales when not requested.

Faced with the possible diagnosis of primary psychosis or behavioral changes secondary to herpetic encephalitis, risperidone was prescribed, as well as lorazepam and acyclovir, although the latter was discontinued because the polymerase chain reaction test to detect herpes simplex virus was negative. The patient remained intermittently agitated and his behavior was severely disorganized. One day, he ran towards his bedroom window, almost jumped out of it and had to be restrained by hospital security.

Brain CT and brain MRI results were normal. A basic metabolic panel showed results within normal limits, and his VDRL test was non-reactive. Cerebrospinal fluid analysis revealed only pleocytosis, at 26 cells $/ \mathrm{mm}^{3}$.

On the ninth hospital day (HD 9), the consultationliaison psychiatric team began to follow up the patient. The first examination of his mental state revealed a wandering gaze, uncooperativeness, normal level of consciousness, global disorientation, attention instability, hypervigilance, labile affect, disaggregated thinking, scarce speech, neologisms, no evidence of delusional activity, no changes on sensory perception, lack of pragmatism, passive negativism, restlessness, involuntary facial movements and verbal perseveration.

The patient remained under observation. Serial electroencephalograms showed diffuse disorganized electrical activity without epileptiform tracings. Antinuclear antibody and lupus anticoagulant tests were negative. Chest, abdomen and pelvis CT scans were all normal. As autoimmune limbic encephalitis was suspected as the most likely diagnosis, an autoantibodies panel was performed using new cerebrospinal fluid and blood samples, and test results revealed positivity for anti-NMDAR.

With an established diagnosis of anti-NMDAR encephalitis, immunosuppressive treatment was initiated, and a testicle ultrasound was performed, which did not reveal any neoplastic findings. Intravenous (IV) immunotherapy followed the recommendations made by Dalmau et al., ${ }^{7}$ and consisted of methylprednisolone (1 g/day), seven plasmapheresis treatments and immunoglobulin $(117.5 \mathrm{~g}$ ). As there were no satisfactory clinical results, other options were from HD 43 on: cyclophosphamide $(1 \mathrm{~g} /$ month for 6 months, continuing after hospital discharge), plasmapheresis and rituximab (675 mg/week for 4 weeks).

Before his first psychiatric evaluation, he was taking lorazepam (1 $\mathrm{mg} /$ day) and risperidone (3 $\mathrm{mg} /$ day) to control episodes of agitation. However, risperidone had to be replaced with quetiapine (50 mg/day) because drug-induced akathisia was suspected. On HD 15, as the patient developed shortterm episodes of autonomic disruption (erythema, hyperthermia, tachycardia, tachypnea, hypertension and restlessness), clonidine ( $0.2 \mathrm{mg} /$ day) was also administered, if necessary. During his first intensive care unit (ICU), lorazepam and quetiapine doses were increased to $15 \mathrm{mg}$ and $700 \mathrm{mg} /$ day from admission to return to the general ward, although benzodiazepines are not recommended when the patient has respiratory failure. In addition, trazodone was introduced gradually to $150 \mathrm{mg} /$ day to improve behavior and sleep. On his second admission to ICU, lorazepam was administered again to avoid the use of drugs to treat agitation, such as propofol. At discharge, on HD 111, psychiatric drugs were quetiapine (75 mg/day), Iorazepam (1 mg/day), trazodone (150 mg/day) and prednisone (40 mg/day) (Figure 1). 


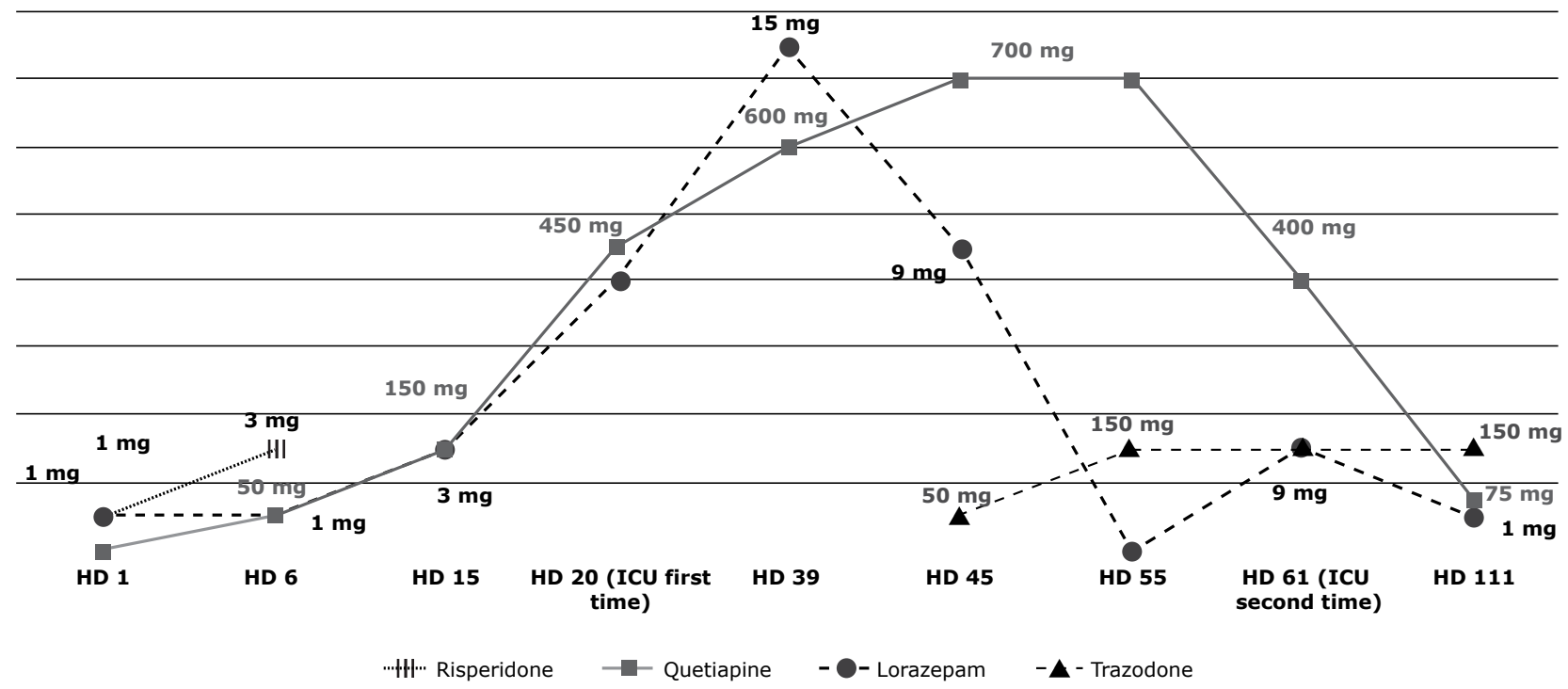

Figure 1 - Psychotropic drugs used to manage psychomotor agitation from admission to discharge. Improvement of behavioral symptoms started after HD $85 . \mathrm{HD}=$ hospital day; $\mathrm{ICU}=$ intensive care unit.

Psychomotor agitation, the main psychiatric complication, may reflect conceptual disorganization, autonomic instability, seizures or dyskinesia, each requiring a specific form of management. Because of that, the patient was physically restrained most of the time and received extra doses of sedatives: IM haloperidol ( 5 $\mathrm{mg}$ ), IV diazepam (5-10 mg) and IV propofol (30-50 mg). On a single day, $20 \mathrm{mg} /$ day of diazepam and $2.5 \mathrm{mg} /$ day of midazolam were administered. Explanations for family and the healthcare team about the characteristics of each complication and the self-limiting nature of restlessness attacks as part of paroxysmal dysautonomia were important to reduce parenteral medication.

During the 111 days that he remained hospitalized, the patient had to be transferred to the ICU twice. First on HD 22, he suddenly developed acute respiratory failure and had to be treated with antibiotics for pneumonia and mechanical ventilation. His breathing pattern gradually improved, he was weaned from mechanical ventilation and returned to the general ward on HD 40. On HD 59, he was transferred to the ICU again due to septic shock secondary to urinary infection. He was treated with vasoactive drugs, mechanical ventilation and antibiotics until he improved clinically, and transferred back to the general ward on HD 87.

From HD 85 on, the patient's interaction with the examiners gradually improved, as demonstrated by his response to some verbal commands, such as to press and release the examiner's hand and to stretch and flex his limbs. This outcome was only possible because of the essential involvement of the psychiatry, speech therapy, physiotherapy, nutrition, occupational therapy and psychology teams, in addition to the neurology team (main clinical assistant).

In the last days of evaluation before discharge, he remained disoriented and reported amnesia during hospitalization. Psychomotor agitation episodes became sparse, controlled due to the verbal support of family members, and autonomic episodes were rare. After discharge, the patient received three more doses of cyclophosphamide. He is currently being followed up in our outpatient service. He still has some degree of apathy, but takes only trazodone (150 mg/day) and prednisone (10 mg/day).

\section{Comments}

Anti-NMDAR encephalitis requires specific treatment (immunotherapy or tumor removal, when detected) that should be initiated as soon as possible to decrease anti-NMDAR levels and ensure good outcomes. Before these measures have an effect, psychiatric management is crucial to minimize the consequences of psychiatric symptoms for patients and clinical teams.

Only a few case reports of anti-NMDAR encephalitis mention the use of psychotropic drugs, and some describe the doses of the medication used. ${ }^{10-12}$ Except for catatonia, for which lorazepam and electroconvulsive therapy are well-established treatments, ${ }^{9}$ no standard drug class, medication or dosage have been defined for anti-NMDAR encephalitis. Low doses of typical 
and atypical agents to treat adult patients have been described in current literature: haloperidol (1-2 mg/day), olanzapine (5 mg/day), aripiprazole $(2.5 \mathrm{mg} /$ day) and risperidone ( $1 \mathrm{mg} /$ day).$^{8,9}$ In two cases of adolescents, van de Riet et al. ${ }^{13}$ described the combination of haloperidol and risperidone, but neither the use of low doses nor slow titration prevented both patients from having extrapyramidal side effects.

Risperidone has been suggested as an early treatment for first episode psychotic disorders because it has less frequent extrapyramidal side effects than typical antipsychotics. ${ }^{14}$ In our case, it was prescribed immediately before quetiapine, because the patient presented with agitation and because akathisia was included in the differential diagnosis. High doses of quetiapine and lorazepam were administered to contain restlessness and were reduced as the patient's neurological status improved.

Trazodone was a good option to treat insomnia, in agreement with previously reported findings. ${ }^{8,10}$ Although promethazine and phenothiazine are possible options for sedation, ${ }^{12}$ their anticholinergic effects may lower the consciousness level and promote delirium.

As consultation-liaison professionals, psychiatrists may help adjust the procedures of the whole healthcare team to treat neuropsychiatric complications that may affect patients with anti-NMDAR encephalitis while hospitalized. ${ }^{13}$ Non-pharmacological interventions should considered in the treatment of agitation and insomnia, as they may prevent the use of more sedative medications that may expose a patient already at risk of clinical deterioration to harmful, and unnecessary, events. Likewise, dangerous conditions, such as malignant neuroleptic syndrome and respiratory failure, should be seen as confounding factors, as they may be outcomes of the disease itself or adverse drug effects. ${ }^{15}$ Furthermore, a multidisciplinary approach is essential for the successful treatment of patients with anti-NMDAR encephalitis and the prevention of physical and cognitive sequelae..$^{8,9}$

This case report contributes information about the psychiatric management of a patient with anti-NMDAR encephalitis, a diagnosis with which psychiatrists should be familiar.

\section{References}

1. Wandinger KP, Saschenbrecker S, Stoecker W, Dalmau J. Anti-NMDA-receptor encephalitis: a severe, multistage, treatable disorder presenting with psychosis. J Neuroimmunol. 2011;231:86-91.

2. Dalmau J, Lancaster E, Martinez-Hernandez E, Rosenfeld MR, Balice-Gordon R. Clinical experience and laboratory investigations in patients with anti-NMDAR encephalitis. Lancet Neurol. 2011;10:63-74.

3. Pollak TA, McCormack R, Peakman M, Nicholson TR, David AS. Prevalence of anti-N-methyl-d-aspartate (NMDA) antibodies in patients with schizophrenia and related psychoses: a systematic review and meta-analysis. Psychol Med. 2014;44:2475-87.

4. Dalmau J, Gleichman AJ, Hughes EG, Rossi JE, Peng X, Lai M, et al. Anti- NMDA-receptor encephalitis: case series and analysis of the effects of antibodies. Lancet Neurol. 2008;7:1091-8.

5. Maneta E, Garcia G. Psychiatric manifestations of anti-NMDA receptor encephalitis: neurobiological underpinnings and differential diagnostic implications. Psychosomatics. 2014;55:37-44.

6. Kayser MS, Titulaer MJ, Gresa-Arribas N, Dalmau J. Frequency and characteristics of isolated psychiatric episodes in anti-N-methyl-daspartate receptor encephalitis. JAMA Neurol. 2013;70:1133-9.

7. Dalmau J, Tüzün E, Wu HY, Masjuan J, Rossi JE, Voloschin A, et al. Paraneoplastic anti-N-methyl-D-aspartate receptor encephalitis associated with ovarian teratoma. Ann Neurol. 2007;61:25-36.

8. Chapman MR, Vause HE. Anti-NMDA receptor encephalitis: diagnosis, psychiatric presentation, and treatment. Am J Psychiatry. 2011;168:245-51.

9. Mann A, Machado NM, Liu N, Mazin AH, Silver K, Afzal KI. A multidisciplinary approach to the treatment of anti-NMDAreceptor antibody encephalitis: a case and review of the literature.J Neuropsychiatry Clin Neurosci. 2012;24:247-54.

10. Barry H, Hardiman O, Healy DG, Keogan M, Moroney J, Molnar PP, et al. Anti-NMDA receptor encephalitis: an important differential diagnosis in psychosis. Br J Psychiatry. 2011;199:508-9.

11. Kung DH, Qiu C, Kass JS. Psychiatric manifestations of anti-NMDA receptor encephalitis in a man without tumor. Psychosomatics. 2011;52:82-5.

12. Kuo $\mathrm{YL}$, Tsai HF, Lai MC, Lin $\mathrm{CH}$, Yang YK. Anti-NMDA receptor encephalitis with the initial presentation of psychotic mania. J Clin Neurosci. 2012;19:896-8.

13. Van de Riet EH, Esseveld MM, Cuypers L, Schieveld JN. AntiNMDAR encephalitis: a new, severe and challenging enduring entity. Eur Child Adolesc Psychiatry. 2013;22:319-23.

14. Zhang JP, Gallego JA, Robinson DG, Malhotra AK, Kane JM, Correll CU. Efficacy and safety of individual second-generation vs. firstgeneration antipsychotics in first-episode psychosis: a systematic review and meta-analysis. Int J Neuropsychopharmacol. 2013;16:1205-18.

15. Jones KC, Benseler SM, Moharir M. Anti-NMDA receptor encephalitis. Neuroimag Clin N Am. 2013;23:309-20.

\section{Correspondence:}

Maila Castro Lourenço das Neves

Mental Health Department

Universidade Federal de Minas Gerais

Av. Professor Alfredo Balena, 190/235, Santa Efigênia

30130-100 - Belo Horizonte, MG - Brazil

Fax: +55 (31) 3409.9785

E-mail: mailacln@gmail.com 